International Journal of Environmental Research and

Public Health

ISSN 1660-4601

www.mdpi.com/journal/ijerph

Review

\title{
Protein-Energy Wasting and Mortality in Chronic Kidney Disease
}

\author{
Alice Bonanni ${ }^{1}$, Irene Mannucci ${ }^{1}$, Daniela Verzola ${ }^{1}$, Antonella Sofia ${ }^{1}$, Stefano Saffioti ${ }^{1}$, \\ Ezio Gianetta ${ }^{2}$ and Giacomo Garibotto ${ }^{1, *}$
}

1 Division of Nephrology, Dialysis and Transplantation, Department of Internal Medicine, Azienda Ospedale Università San Martino, Genoa University, Viale Benedetto XV 6, Genoa, Italy; E-Mails: alice.bonanni@libero.it (A.B.); ire28182@yahoo.it (I.M.); daverz@libero.it (D.V.); antonella.sofia@unige.it (A.S.); stesaf@unige.it (S.S.)

2 Department of Surgery, Azienda Ospedale Università San Martino, Genoa University, Largo R. Benzi, Genoa, Italy; E-Mail: gianetta@unige.it

* Author to whom correspondence should be addressed; E-Mail: gari@ unige.it; Tel.: +39-010-3538989; Fax: +39-010-3538899.

Received: 25 February 2011; in revised form: 29 April 2011 / Accepted: 3 May 2011 / Published: 19 May 2011

\begin{abstract}
Protein-energy wasting (PEW) is common in patients with chronic kidney disease (CKD) and is associated with an increased death risk from cardiovascular diseases. However, while even minor renal dysfunction is an independent predictor of adverse cardiovascular prognosis, PEW becomes clinically manifest at an advanced stage, early before or during the dialytic stage. Mechanisms causing loss of muscle protein and fat are complex and not always associated with anorexia, but are linked to several abnormalities that stimulate protein degradation and/or decrease protein synthesis. In addition, data from experimental CKD indicate that uremia specifically blunts the regenerative potential in skeletal muscle, by acting on muscle stem cells. In this discussion recent findings regarding the mechanisms responsible for malnutrition and the increase in cardiovascular risk in CKD patients are discussed. During the course of CKD, the loss of kidney excretory and metabolic functions proceed together with the activation of pathways of endothelial damage, inflammation, acidosis, alterations in insulin signaling and anorexia which are likely to orchestrate net protein catabolism and the PEW syndrome.
\end{abstract}


Keywords: protein-energy wasting; malnutrition; chronic kidney disease; cardiovascular risk; skeletal muscle

\section{Protein Energy Wasting (PEW) in CKD: Clinical Implications}

In spite of the advancements in current techniques of renal replacement therapy, mortality levels remain high in patients with CKD [1]. This increase in mortality is not only limited to dialysis patients, but includes the whole ranges of GFR during the progression of CKD [2,3] and is mainly due to cardiovascular disease (CVD) and, at advanced stages, to infections [4]. The prevalence of protein energy wasting (PEW), a condition of loss of muscle and visceral protein stores not entirely accounted for by inadequate nutrient intake [5] increases progressively along with the loss of residual renal function and is high in dialysis patients [5].

Uremia-induced alterations in protein metabolism and gastrointestinal tract function can result in poor nutritional status, which in turn increases the risks of CVD and infection. The classical risk factors for CVD (such as old age, lifestyle, smoking, hypertension, dyslipidemia, diabetes, left ventricular hypertrophy, hearth failure) are over-expressed in CKD patients, partly because of the clinical characteristics of the CKD population (which consists mainly of old subjects, with many of them affected by CVD and type II diabetes) [6]. However, the excess of cardiovascular risk related to CKD may be due in part to a higher prevalence of non-traditional risk factors peculiar to CKD which per se may promote endothelial dysfunction and/or atherogenesis [1].

An example of the relevance of non-traditional risk factors is offered by the phenomenon of the "reverse epidemiology" in dialysis patients [7]. While in the general population a high body mass index (BMI; $\mathrm{Kg} / \mathrm{m}^{2}$ ) is associated with an increased cardiovascular risk and with all-cause mortality, in dialysis patients the effect of overweight or obesity is paradoxically in the opposite direction, with a higher BMI leading to an improved survival [7]. The "reverse epidemiology" phenomenon involves also several other traditional risk factors, such as blood pressure and serum concentrations of cholesterol, homocysteine, and creatinine [8]. In addition, during the course of progressive decline in renal function, the profile of risk for death may change because the occurrence of others risk factors, such as progressive wasting [9], and inflammation [10], which may play an increasing role and may outweigh the effects of traditional risk factors. Chmielewski et al. [11] recently showed that apoB/apoA-I ratio is associated with greater survival in hemodialysis (HD) patients only in the short term (1-year mortality).Similar data were obtained in another study [12], where the reverse association between hypercholesterolaemia and all-cause mortality declined gradually after the first year of follow up. This is probably due to the temporal impact of competing risks.

Liu et al. [13] recently postulated that the paradoxical relationship between cholesterol level and mortality could be explained by the effect of the presence of the complex malnutrition-inflammation (defined as BMI $<23 \mathrm{~kg} / \mathrm{m}^{2}$ or C-reactive protein $>10 \mathrm{mg} / \mathrm{L}$ ) in the dialysis population. Recently, Contreras et al. [14] assessed the prevalence of malnutrition-inflammation and its modifying effects on the risk-relationship of cholesterol levels with subsequent CVD events in African American with hypertensive CKD. They showed that the hazard ratio for the primary CVD outcome increased as total cholesterol increased in subjects without malnutrition-inflammation, whereas it tended to decrease in 
subjects with malnutrition-inflammation. It should be considered that the phenomenon of "reverse epidemiology" is not exclusive of renal patients, but is also observed in sarcopenia of aging [15] and in chronically wasted patient groups affected by chronic heart failure, HIV infection or cancer [16] suggesting that the effects of wasting may overcome those of traditional risk factors for cardiovascular disease.

The aim of this work is to review the mechanisms responsible for PEW, while providing a summary of the non-traditional factors which increase the cardiovascular risk in CKD patients. The mechanisms underlying the causes of the wasting syndrome are beginning to be understood and include the loss of kidney metabolism and function as well as the activation of pathways of endothelial damage, inflammation, acidosis, altered intracellular IGF-1 and insulin signaling. These factors overlap with those already operating in ageing and in comorbid conditions, such diabetes and sepsis, and are likely to orchestrate the PEW syndrome.

\section{Biomarkers/Proxies for Malnutrition and Mortality in CKD}

Several biomarkers have been associated with worse outcomes in CKD and dialysis patients. Among these, those of PEW appear to be the strongest predictor of survival [9]. Lower serum albumin [17], prealbumin [18], cholesterol [13], serum transferrin [18], creatinine [19] and bicarbonate [20] levels are associated with mortality in dialysis patients. Other biochemical markers that are directly or indirectly linked to PEW and outcomes include various hormones such as testosterone [21], leptin [22], visfatin [23], adiponectin [22] and thyroid hormones [24,25]. The mechanisms of action responsible for the adverse outcomes associated with PEW markers remain unclear: it is likely that a combination of factors are responsible, rather than a single etiologic mechanism [9].

\subsection{Hypoalbuminemia}

Hypoalbuminemia is the most commonly used surrogate of PEW in dialysis patients and has a strong association with increased mortality [17] and morbidity [26]. Hypoalbuminemia is associated with development of de novo and recurrent cardiac failure in HD and CAPD patients [27]. The use of serum prealbumin has been advocated as a better surrogate of nutritional status than albumin in dialysis patients [28]. A confounding factor is that serum albumin and prealbumin are also negative acute phase reactants and their serum levels are profoundly affected by the presence of an inflammatory response. It is already known from studies in 1940s (the "Minnesota Experiment"), that albumin levels are extraordinarily preserved, while fat an muscle mass is lost, when nutrient intake is curtailed [29]. Also CKD patients compliant with a restricted protein and energy intake do not show a remarkable decrease of serum albumin levels [30,31]. In dialysis patients, hypoalbuminemia could also be favoured by the loss of amino acids and/or protein during renal replacement therapy [32]. Therefore, it is not clear whether the negative clinical outcome in advanced CKD patients associated with hypoalbuminemia is a reflection of nutrition or of the inflammatory response or both. It is also not clear whether the relationship between hypoalbuminemia and increased mortality in dialysis patients stems from the intrinsic effects of albumin, or hyopoalbuminemia represents the occurrence of ongoing events associated with increased mortality risk. Low albumin may be associated with hypercoagulable 
states [33], and increased blood viscosity [34]. Moreover, low oncotic pressure may adversely affect water shift between the intravascular and interstitial space. Albumin also has important roles as a scavenger of free radicals, is a binding agent for toxic compounds and a carrier for a wide variety of drugs and hormones [35]. Reduced albumin binding of drugs and endogenous ligands is a feature of uremia [36].

\subsection{Oxidative Stress}

Oxidative stress results from an imbalance between oxidant generation and anti-oxidant defense mechanisms, leading to cell and tissue injury. It is consistently accepted that in CKD patients a deficiency in the antioxidant systems combines with an increase in pro-oxidant activity owing to advanced age, diabetes, chronic inflammation, sepsis and the bio-incompatibility of dialysis membranes and solutions. Nguyen-Khoa et al. [37] found a direct correlation between lipid and protein oxidation markers and CRP levels; in addition, plasma alpha-tocopherol resulted inversely correlated with CRP levels and with the duration of dialytic treatment [37]. The accumulation of AGEs observed in CKD could be partly due to a reduced renal clearance of these compounds, but also to an increased de novo generation, stimulated by oxidative stress and inflammation. AGEs could play an important role in the development of atherosclerosis, by stimulating the activation of mononuclear cells (thus inducing endothelial dysfunction) and also by modifying LDLs, which become less able to be cleared by the LDL receptors [38]. Moreover, the interaction between AGEs and their receptors (RAGEs), could lead to the generation of intracellular oxidative stress and inflammatory mediators through the NF-kB pathway [39]. These mechanisms could explain the role of AGEs in the high frequency of CVD and increased all-cause mortality. Nakashima et al. [40] found that both sRAGE and the RAGE ligand S100A12 are elevated in CKD patients. However, while a direct correlation was observed between S100A12 and CRP, IL-6 and cardiovascular mortality, sRAGE resulted negatively associated with CRP and didn't predict mortality.

Advanced oxidation protein products (AOPPs) are a class of dityrosine-containing protein products, which arise from the reaction between chlorinated oxidants and plasma proteins. AOPPs could play a role in the progression of $\mathrm{CKD}$, since they induce podocyte apoptosis through the activation of NADPH-oxidase [41]. In addition, AOPPs can trigger the phagocyte nicotinamide adenine dinucleotide phosphate (NADPH) oxidase and myeloperoxidase (MPO)-dependent activities [42]. Descamps-Latscha et al. [43] found a direct correlation between CRP, fibrinogen, AOPP levels and incident first occlusive atherosclerotic cardiovascular events in CKD patients. Some possible errors in the determination of AOPPs in plasma derive from their UV detection since triglycerides and other particles determining turbidity may interfere in their quantitation and cause their overestimation. Valli et al. [44] showed a strong correlation between triglycerides and AOPPs not only in CKD patients, but also in healthy controls.

\subsection{Microinflammation}

Several visceral proteins and hormones which decrease in blood in response to malnutrition (such as albumin, prealbumin, transferrin, retinol binding protein and IGF-I) are also negative acute-phase proteins and their liver synthesis is depressed by inflammation. Several investigators have shown that a 
significant percentage of chronic hemo- and peritoneal dialysis patients have increased levels of pro-inflammatory cytokines (IL-1, IL-6, TNF alpha) suggesting that a systemic inflammatory response is common in dialysis-treated patients [45,46]. Moreover, cross-sectional studies suggest that inflammation is responsible for serologic and anthropometric evidence of malnutrition [46]. Elevated CRP is strongly associated with cardiovascular mortality [47], so that the association between inflammation and atherosclerosis seems to be particularly strong in dialysis patients. Although precise mechanisms that contribute to the high prevalence of inflammation in CKD are unknown, ROS have been proposed as a potential contributor. On one hand, oxidative stress is able to activate transcriptor factors, such as NF-kB, which regulate inflammatory mediator gene expression. On the other hand, chronic inflammation may cause increased oxidative stress, thus creating a vicious circle in the determination of cardiovascular risk in CKD patients.

Notably, CRP and IL-6 levels increase progressively along with the decline of glomerular filtration rate in CKD patients [45,48]. These effects could be due to reduced kidney excretory function, since at least some pro-inflammatory cytokines are excreted through the kidney. In addition, haemodialysis may activate an inflammatory cascade, because of the exposure of blood to bioincompatible dialysis membranes and/or backfiltration of lipopolysaccharide through the dialysis membranes [49].

Pro-inflammatory cytokines may cause anorexia, induce resistance to GH and IGF-I [50] and increase energy expenditure [51]. CRP per se may induce vascular damage, since CRP formed locally in the kidney reduces nitric oxide production and induces monocyte recruitment and foam cell formation [52].

New inflammatory markers are coming into play. Pentraxin-3 (PTX3), an inflammatory mediator structurally linked to CRP produced by vascular endothelial cells and macrophages in response to pro-inflammatory signals, has been shown to be elevated in haemodialysis patients [53], and has been identified as a novel mortality risk factor in incident dialysis patients and CKD patients, independent of traditional risk factors, CRP and flow-mediated dilation [54,55]. Of interest, fat also seems to be a significative source of PTX3 [56].

Another recently identified biomarker of inflammation in CKD patients is CD14. This molecule is a pattern-recognition receptor that plays a central immunomodulatory role in pro-inflammatory signaling in response to a variety of ligands, including endotoxin. CD14 protein is present both in soluble (sCD14) and membrane-bound forms. Raj et al. [57] showed an association between sCD14 levels and the presence of PEW in hemodialysis patients, probably due to cytokine activation.

\section{Effect of Body Composition on the Risk of Mortality of CKD Patients}

The protective effect of large body size in dialysis patients may be associated with higher adipose tissue and fat reserves. This appears to be somewhat contradictory, since adipose tissue, especially visceral fat, has pro-inflammatory properties. As an alternative explanation, the "protective" effect of BMI might be related to fat-free mass. Even though fat tissue is related to inflammation in the general population, in dialysis patients it may be associated with relatively greater secretion of anti-inflammatory cytokines, such as adiponectin, than pro-inflammatory molecules [58]. There is no difference in plasma inflammatory markers (IL-6, TNF- $\alpha$, and CRP) in individuals with different proportions of body fat [59]. A limited number of studies have examined the relative contributions of 
fatty mass (FM) and lean body mass (LBM) to clinical outcomes in CKD patients who undergo maintenance haemodialysis $[60,61]$. Some of these studies have suggested that the protective effect of high BMI against mortality is related to higher FM [62].

Recent findings suggest that the type and the distribution of fat rather than its total amount play a role in the determination of risk [63]. Particularly, abdominal fat accumulation is a mortality risk factor, since it is a source of pro-inflammatory adipokines [64]. Both leptin and visfatin seem to play a role in CVD and endothelial dysfunction [65,66] and the receptors of these adipokines are highly expressed in atherosclerotic plaques [67,68]. Ramkumar et al. [69] however, suggested that the protective effect of $\mathrm{BMI}$ in the maintenance haemodialysis population is mostly conferred to those patients with a higher LBM (muscle mass), estimated by urine creatinine content. Huang et al. [70] recently reported that low mid-arm muscle circumference (MAMC), a surrogate of LBM, and low triceps-skinfold thickness, an indicator of FM, were each associated with higher all-cause mortality in haemodialysis patients. Higher FM in both sexes and higher LBM in women appear to confer a protective effect. However, the survival advantage of FM appears to be superior to that of LBM [71].

\section{Mechanisms of PEW}

\subsection{Altered Amino Acid and Protein Handling by the Diseased Kidney}

The human kidney plays a major role in the homeostasis of body amino acid pools. The kidney is the major organ for the disposal of glutamine and proline from the arterial blood, and for the net release of some amino acids such as serine, tyrosine and arginine, which are newly generated within the kidney for export to other tissues [72,73]. The magnitude of the net release or uptake of amino acids by the normal kidney can be understood if one considers that in a $70 \mathrm{Kg}$ man the daily net production of serine is $\sim 3-4 \mathrm{~g}$, that of tyrosine $\sim 1 \mathrm{~g}$, that of arginine $\sim 2$ grams. In addition the human kidney plays also a major role in the removal of glutathione [74], and of S-adenosylhomocysteine $(\mathrm{SAH})$ [75]. Besides that, the kidney also releases smaller amounts $(<1 \mathrm{~g} /$ day $)$ of threonine, lysine and leucine into the systemic circulation [72].

The human kidney plays also a major role in whole body protein metabolism and amino acid oxidation [76,77] as well as in the regulation of plasma levels of several hormones and peptide compounds (i.e., prostaglandins, thyroid hormone, parathyroid hormone, insulin, growth hormone (GH), 1,25 dihydrocholecalciferon), whose concentrations and effects result therefore altered in renal failure.

\subsection{The Kidney and Methionine Transmethylation}

The biological effects of methionine transmethylation, by which the methyl group of S-Adenosylmethionine (SAM) is donated to a large variety of acceptor substrates, is needed for the synthesis of a wide range of compounds such as membrane phospholipids, neurotransmitters, proteins, creatine and hormones [76]. Methylation processes play also a major role in the epigenetic regulation of protein expression and changes in human DNA methylation patterns are an important feature of many diseases, including atherosclerosis and cancer [78]. S-adenosylhomocysteine (SAH) is the by-product of methionine transmethylation and the precursor of homocysteine. Since SAH is a potent 
feedback inhibitor of most methyltransferases, including the methionine remethylation pathway, this compound plays an essential role in the control of the overall transmethylation rates [76]. Thus, the efficiency of methyltransferase reactions is dependent on efficient tissue removal of SAH [79]. Recent experimental [80] and clinical evidence [81] also suggests that the accumulation of SAH in body fluids, rather than increased homocysteine levels, is associated with vascular disease and tissue damage. Posttranslational modification of proteins, associated with high SAH intracellular accumulation, has been described in patients with CKD [82]. To explore the sites and mechanisms underlying the regulation of circulating SAH levels, we measured plasma SAH across the kidney, splanchnic bed and lung in humans [75]. Our results showed that the human kidney plays a unique role in the removal of SAH from the circulation, indicating that the kidney may have an important role in the control of body transmethylation reactions.

\subsection{The Kidney and Nitric Oxide (NO) Synthesis}

In the endothelium, a central regulatory reaction is the generation of NO from L-arginine, which is controlled by NO synthase. It is of note that the NO production is decreased in CKD patients [83]. There are many causes to explain the NO deficiency. One obvious cause is that limited arginine provision by diseased kidney hinders tissue availability of this amino acid. However, a decrease in arginine levels is rarely observed in CKD patients suggesting the existence of sources of arginine other than the kidney [76]. In patients with advanced renal disease, anorexia could blunt nutritional intake, thus further curtailing tissue arginine pools. NO deficiency could be induced by increased reactive oxygen species (ROS) generation and by decreased tetrahydrobiopterin (BH4), an important cofactor for NOS [84]. In addition, the accumulation in blood fluids of NO Synthase inhibitors, such as asymmetric dimethilarginine (ADMA) could explain the strong association between ADMA and carotid atherosclerosis as wall as with overall and cardiovascular mortality [85]. Initially, it was assumed that the increased plasma ADMA in ESRD reflected loss of renal clearance [86]. However, very little ADMA is excreted unchanged in the urine and the majority is broken down by the enzymes dimethylarginine dimethylaminohydrolase 1 and 2 (DDAH1 and 2). DDAH is widely distributed and is most abundant in the kidney and also highly expressed in the liver [85]. Decreased metabolism by DDAH could be a further cause for ADMA accumulation in CKD patients. ADMA appears to be involved in CKD progression, since elevated concentrations of ADMA are associated with the development of renal fibrosis in animals [87]. These data suggest that in pathophysiological conditions of endothelial dysfunction, the exaggerated endogenous synthesis of ADMA could contribute to CKD progression by favoring hypertension and extracellular matrix synthesis. Short-term reduction of circulating ADMA by hemodialysis is associated with amelioration of endothelial dysfunction in patients with ESRD [88].

\subsection{Resistance to $G H / I G F-1$}

Resistance to $\mathrm{GH}$ is responsible for the defective growth of uremic children. Besides its stimulatory effects on growth and anabolism, circulating GH and IGF-1 levels may play a role in the metabolic response to fasting, by contributing to protein conservation [72]. Growth hormone $(\mathrm{GH})$ resistance is common in uremia and together with resistance to insulin-like growth factor-1 (IGF-1) contributes to 
muscle wasting. Development of GH resistance in uremia stems from reduced IGF-1 synthesis [89], sensitivity [90] or bioavailability [91], but also to impaired GH signal transduction [92]. Defective intracellular GH signaling may stem from impaired GH stimulated Jak2-STAT5 phosphorylation, which may be the result of inflammation induced SOCS2 expression [92]. In addition, the hepatic resistance to GH-induced IGF-1 expression in uremia arises due to defects in STAT5b phosphorylation and its impaired binding to DNA, processes further aggravated by inflammation [93].

Besides uremia per se, the effectiveness of GH might also be attenuated by other factors often found in CKD patients, such as metabolic acidosis [94] and low nutrient intake [95]. We recently observed [96] that the GH acute anabolic response regarding two different GH receptor-downstream pathways (potassium and amino acid metabolism) is overall preserved in patients with advanced CKD, while it is blunted in patients displaying evidence of microinflammation, suggesting a role for inflammatory changes in the regulation of skeletal muscle protein balance.

\subsection{Low Testosterone}

Multiple anabolic signals, which include both an increase in the regenerative potential and protein metabolism are activated by androgens. Testosterone stimulates myoblasts and satellite cell proliferation to promote repair of muscle damage [97]. In addition, testosterone stimulates muscle protein synthesis [98].

Testosterone concentrations decline with aging and chronic disease $[99,100]$ and are correlated to worse survival [101,102] and mortality due to cardiovascular disease [103]. Among men treated with hemodialysis, testosterone concentrations inversely correlate with all-cause and CVD-related mortality, as well as with markers of inflammation, which suggests that hypogonadism may be an additional treatable risk factor for patients with CKD [104,105].

\subsection{Insulin Resistance and Altered Insulin Signaling}

Insulin is a key regulating factor of protein metabolism for the conservation of lean body mass. Even small increases in blood insulin levels, well within the physiological range, are associated with pronounced suppression of protein breakdown [106]. A post-receptor defect in muscle responsiveness to insulin is the cause of insulin resistance with regard to glucose metabolism occurring in CKD patients [72]. However, it is not understood whether insulin resistance regarding glucose metabolism also extends to the antiproteolytic action of this hormone. If so, it would contribute to the muscle wasting which is often found in uremic patients. Bailey et al. recently identified a series of abnormal postreceptor signaling changes in the insulin/IGF-1 pathway in muscle of rats with CKD [107]. These included the occurrence of functional abnormalities in the IRS/PI3-K cascade that decrease the phosphorylation of the downstream effector Akt. The low phosphorylated Akt activity has been shown to stimulate the expression of specific E3 ubiquitin conjugating enzymes, atrogin-1/MAFbx and MuRF1, in muscle. Further, a decrease in muscle PI3K activity could activate Bax leading to stimulation of caspase-3 activity and increase protein degradation [107]. These defects which are specific to uremia can overlap with those due to diabetes in patients with diabetic kidney disease. Pupim et al. reported that patients with ESRD secondary to DM have an acceleration of loss of lean body mass as compared with nondiabetic CKD patients [108]. 
Metabolic acidosis is a common complication of advanced CKD and may represent another factor associated with increased insulin resistance. Acidosis increases protein degradation through an upregulation of the ATP-dependent, ubiquitin-requiring pathway [109]. Correction of metabolic acidosis with bicarbonate supplementation has been demonstrated to improve insulin resistance in animal models of uremia as well as in humans [110].

\subsection{Anorexia}

Anorexia, together with nausea and vomiting, is one of the signs of uremic intoxication. In addition to uremia per se, other possible causes of anorexia in CKD patients include gastroparesis (diabetic nephropaty), depression and systemic disease (i.e., SLE, congestive hearth failure). Anorexia contributes with inflammatory state to the determination of PEW. Moreover, anorexia is associated with increased mortality risk in hemodialysis patients [111]. Uremia may cause anorexia through the accumulation of toxic molecules, pro-inflammatory cytokines, and middle-size molecules which can inhibit appetite. Cheung et al. [112] found that the injection of agouti-related protein (AgRP) in the lateral ventricle of mice with subtotal nephrectomy induced an increase in food intake and body growth, thus suggesting that uremia could cause a defect in the capacity of AgRP to block the melanocortin-4 receptor, MC4-R. Kalantar Zadeh et al. [113] showed an association between anorexia and higher concentration of proinflammatory cytokines, hypo-responsiveness to erythropoietin, hospitalization rates and all-cause mortality in hemodialysis patients.

Carrero et al. recently found a correlation between appetite, malnutrition, inflammation and outcome in hemodialysis patients [114]. Moreover, they shown a greater susceptibility to inflammation-induced anorexia in men, as compared to women, in agreement with the recent finding in rats of sex specific orexigenic and anorexigenic mechanisms in response to inflammation [115].

\section{Ageing and Protein Metabolism}

In several Western countries, persons over the age 65 are expected to soon become the majority of those who will need renal replacement therapy. Nutritional problems are common in elderly patients with ESRD and contribute to the debility and morbidity in this group of dialysis patients [116]. Low dietary intake and diminished muscle masses are both common in the old individuals and may cause low values of BUN and serum creatinine, even in the presence of advanced renal failure [117].

A decrease in body protein is a major characteristics of ageing [118,119]. It involves mainly muscle proteins, and is associated with decreased muscle strenght and functional impairment. Whole body protein synthesis and degradation are similar in young and elderly adults, when results are expressed per lean body mass $[120,121]$. However, selected deficits are specific to certain muscle protein components, such as myosin heavy chain and mitochondrial protein [122]. In addition, in elderly subjects a decrease sensitivity of insulin action regarding protein metabolism have been described [123]. These alterations in protein metabolism due to senescence likely potentiate those caused by uremia. Weight loss in older adults is highly predictive of increased morbidity and mortality $[124,125]$. Several factors contribute to weight loss in older adults. Available data indicate that excess cytokine elaboration may be a critical factor in the induction of involuntary weight loss in older adults. Aging is associated with increased concentrations of TNF-alfa, IL-6, IL1 receptor 
antagonist, and soluble TNF receptor. Acute phase proteins such as C-reactive protein and serum amyloid-A are also elevated, which suggests the activation of the entire inflammatory cascade.

\section{Infections}

Chronic uremia is considered a state of acquired immunodeficiency [126] and CKD patients are at high risk for infection [127]. Among participants in the HEMO Study [128] who died during follow-up, infection was the primary cause of death in $23 \%$. The overall probability of death during an infection-related hospitalization was 15\%. Numerous factors, including advanced age, diabetes, hypoalbuminemia, immunosuppressive therapy, dialysis catheters, the dialysis procedure and uremia per se potentially predispose CKD patients to infections (Figure 1). Malnutrition causes defective immune function because of enhanced susceptibility to infections and deficient damage healing [129]. There are nutrients such as arginine and glutamine which can improve the immune response [130-132]. CKD patients are predisposed to zinc [133,134], vitamin B6 (pyridoxine), vitamin C and folic acid deficiencies [135,136], which can lead to alterations in host defense.

Figure 1. Major mechanisms promoting infections in patients with chronic kidney disease.

\section{MAJOR MECHANISMS FAVORING INFECTIONS IN CKD PATIENTS}

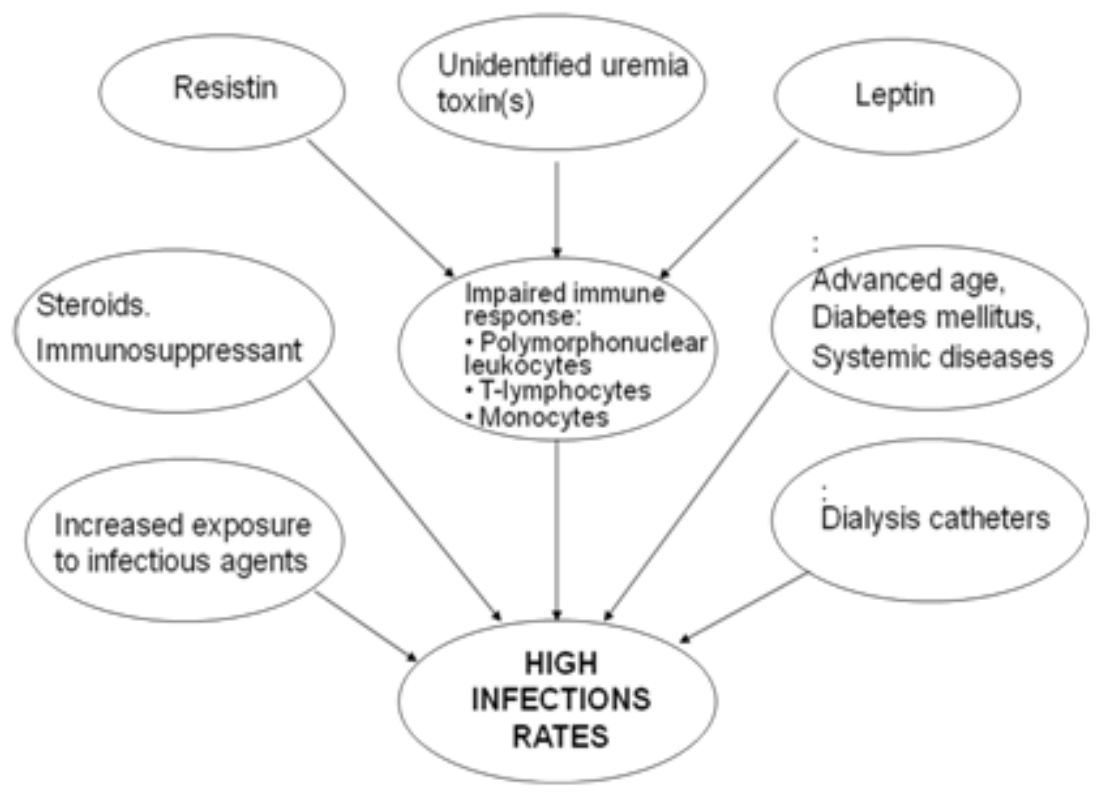

The function of polymorphonuclear white blood cells, lymphocytes, and monocytes is altered in ESRD patients [137-139]. Malnutrition, increased intracellular calcium, iron overload, dialysis membranes, and uremic toxins (i.e., circulating factors that inhibit granulocytes) contribute to impaired polymorphonuclear leukocyte function [126,138]. In addition, T lymphocyte [140], monocyte, and monocyte-derived dendritic cell function is also impaired [141]. Leptin, which accumulates in CKD patients, also plays a role in innate and acquired immunity [142,143]. In fact, leptin and its receptor share structural similarities with IL-6, IL-11, and IL-12 [144,145]. Leptin regulates T lymphocyte responses [146] and increases the secretion of several cytokines by endotoxin-stimulated peritoneal 
macrophages [147]. In addition, leptin induces the expression and secretion of IL-1 receptor antagonist (IL-1Ra) by human monocytes [148] as well as the production of TNF and IL-6 [149]. Recent findings show that leptin positively modulates mononuclear cell survival by interfering with the apoptotic process [150]. More striking, hypoleptinemia characterizing starvation is strictly related to increased susceptibility to infection secondary to malnutrition [146,151]. Thus, leptin is now considered as an adipokine which is capable of linking metabolism and immune homeostasis [151,152]. In addition has been observed that leptin inhibits neutrophil migration in response to classical chemoattractants.

The serum levels of resistin, a $12-\mathrm{kDa}$ protein expressed in inflammatory cells, are increased in patients with CKD and/or diabetes [153,154]. These patients have an increased risk of infections because of an impaired polymorphonuclear leukocyte (PMNL) functions. Cohen et al. observed that resistin interferes with chemotaxis and oxidative burst of PMNL and that p38 MAPK, ERK (p44/42) and PI3K are involved in the regulation of PMNL chemotaxis. Resistin inhibits PNMLs at the high concentrations found in serum of uremic patients, but not in concentrations in healthy subjects [155].

\section{A New Perspective: Accelerated Loss of Myonuclei and Defective Regenerative Potential in the Skeletal Muscle of CKD Patients}

Decrease in nutrient intake, metabolic acidosis, physical inactivity, diabetes, and sepsis are conditions associated with $\mathrm{CKD}$ which can promote muscle wasting through an increase in protein degradation and or a decrease in protein synthesis [156-160]. In addition, the balance between cell loss and regeneration can hinder muscle size and function. The role of apoptosis is a new concept in the regulation of muscle size and function in physiology and disease [161,162]. During atrophy nuclei are lost by apoptosis, while during hypertrophy new nuclei are added to the fibres from muscle stem cells (satellite cells) [161,162]. A same signal can theoretically cause cell and protein loss, since Akt can mediate the effects of PI3-kinase on different events, such as apoptosis [163-165] and protein catabolism [165]. These effects may be especially injurious in uraemia, where impaired Insulin-like Growth Factor I (IGF-I) signaling causes abnormal protein metabolism in muscle and decreases the proliferation of satellite cells [166]. Zhang et al. observed that transcription factors presents in myonuclei, MyoD and myogenin, are reduced in intact and injured muscle of CKD mice. They also found that in satellite cells of injured muscle the expression of myogenic factors mRNAs is impaired in CKD, while it is stimulated in normal injured muscle [166,167].

Recently, we analyzed muscle apoptosis and myostatin mRNA and their related intracellular signals in rectus abdominis samples obtained from CKD patients scheduled for peritoneal dialysis. Apoptotic loss of myonuclei was 3-5 fold increased. In addition myostatin and IL-6 gene expressions were enhanced by $\sim 50 \%$, while levels of IGF-I mRNA were lower than in controls. Phosphorylated JNK and its downstream effector, p-c-Jun, were upregulated, while p-Akt was markedly downregulated. Multivariate analysis models revealed p-Akt and IL-6 to contribute individually and significantly to the prediction of apoptosis and myostatin gene expression, respectively. These findings demonstrate the occurrence of the activation of multiple pathways to promote muscle atrophy in skeletal muscle of CKD patients. Both apoptosis of myonuclei and myostatin are upregulated. However, they appear to be associated with different signals, suggesting that their intracellular pathways are differently regulated in CKD patients [168]. 
Changes in muscle metabolism of specific amino acids induced by uremia could impair muscle regeneration. In patients with $\mathrm{CKD}$, a reduced release of valine and leucine from muscle is likely responsible for their reduced levels in blood [169]. It has been supposed that an increased muscle degradation of valine, probably due to metabolic acidosis [165] and /or an impaired glucose utilization, accounts for the low release of this amino acid from peripheral tissues. Studies in rats and humans with CKD indicate that the correction of metabolic acidosis raises both plasma and muscle BCAA levels by decreasing the transamination and decarboxylation in muscle [170,171]. During the course of CKD, abnormalities due to decreased nutrient intake overlap those caused by acidosis, and the declining plasma valine levels have been reported as an index of poor nutrition and reduced lean body mass [172]. It is of note that leucine cooperates with IGF-1 in stimulating the activation of myogenic satellite cells. These cells are responsible for muscle regeneration in different situations, such as damage-induced muscle loss, aging and progressive neuromuscular diseases. The leucine-induced activation of satellite cells is obtained through the mammalian target of rapamycin (mTOR) signaling, one of the main pathways responsible for protein synthesis and cells proliferation. These effects appear to be due to Beta-hydroxy-beta-methilbutyrate (HMB), a leucine catabolite, which may induce myoblasts proliferation, Akt phosphorylation, and prevent muscle wasting in vitro [173].

In conclusion, PEW is common in patients with CKD and is associated with an increased death risk. However, while even minor renal dysfunction is an independent predictor of adverse cardiovascular prognosis, PEW becomes clinically manifest at an advanced stage, early before or during the dialytic stage. Mechanisms causing loss of muscle protein and fat are complex and not always associated with anorexia, but are linked to several abnormalities that stimulate protein degradation and/or decrease protein synthesis (Figure 2). In addition, data from experimental CKD indicate that uremia specifically blunts the regenerative potential in skeletal muscle, by acting on muscle stem cells. During the course of CKD, the loss of kidney excretory and metabolic functions proceeds together with the activation of pathways of endothelial damage, inflammation, acidosis, resistance to anabolic hormones, and defective insulin signaling. These factors may overlap those already operating in ageing and in comorbid conditions, such as diabetes and sepsis to orchestrate the PEW syndrome.

Figure 2. Scheme of major mechanisms promoting PEW in patients with chronic kidney disease.

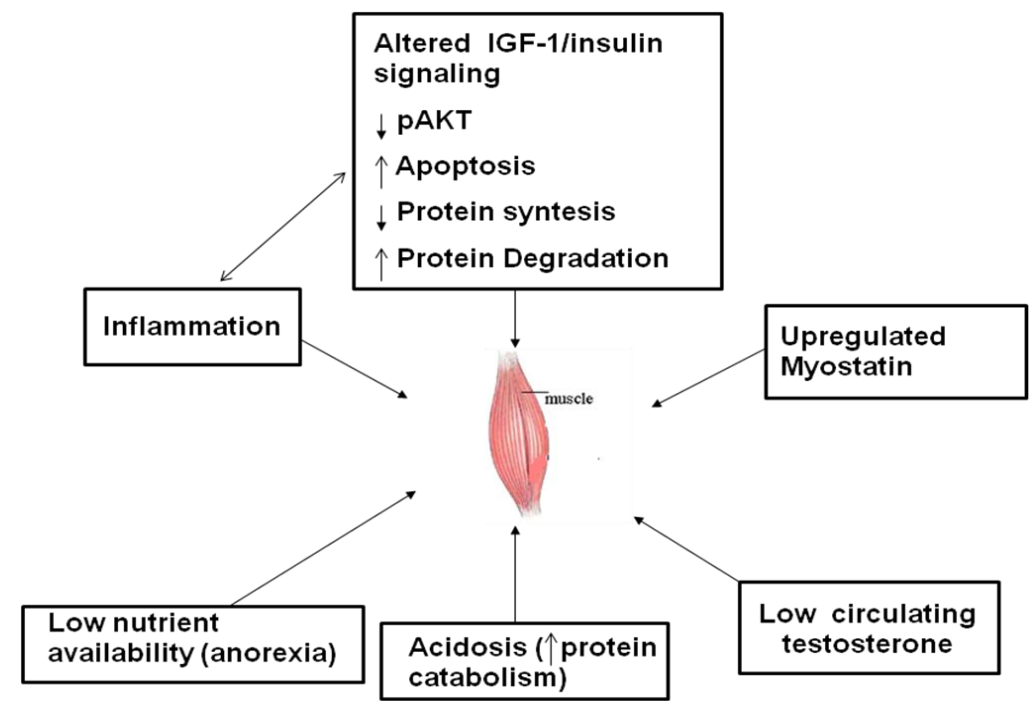




\section{Acknowledgements}

This study was supported by grants from the Ministero dell' Università e della Ricerca Scientifica e Tecnologica (Prin 2007) and Fondazione CARIGE (2009).

\section{References}

1. Kalantar-Zadeh, K.; Abbott, K.C.; Kronenberg, F.; Anker, S.D.; Horwich, T.B.; Fonarow, G.C. Epidemiology of dialysis patients and heart failure patients. Semin. Nephrol. 2006, 26, 118-133.

2. Culleton, B.F.; Larson, M.G.; Wilson, P.W.; Evans, J.C.; Parfrey, P.S.; Levy, D. Cardiovascular disease and mortality in a community-based cohort with mild renal insufficiency. Kidney Int. 1999, 56, 2214-2219.

3. Al-Aly, Z.; Zeringue, A.; Fu, J.; Rauchman, M.I.; McDonald, J.R.; El-Achkar, T.M.; Balasubramanian, S.; Nurutdinova, D.; Xian, H.; Stroupe, K.; et al. Rate of Kidney function decline associates with mortality. J. Am. Soc. Nephrol. 2010, 21, 1961-1969.

4. Himmelfarb, J.; Ikizler, T.A. Hemodialysis. N. Engl. J. Med. 2010, 363, 1833-1845.

5. Foque, D.; Kalantar-Zadeh, K.; Kopple, J.D.; Canau, N; Chauveau, P.; Cuppari, L.; Franch, H.; Guarnieri, G.; Ikizler, T.A.; Kaysen, G.; et al. A proposed nomenclature and diagnostic criteria for protein-energy wasting in acute and chronic kidney disease. Kidney Int. 2008, 73, 391-398.

6. Locatelli, F.; Manzoni, C.; Del Vecchio, L.; Di Filippo, S. Changes in the clinical condition of haemodialisys patients. J. Nephrol. 1999, 12, S82-S91.

7. Kalantar-Zadeh, K.; Block, G.; Humphreys, M.H.; Kopple, J.D. Reverse epidemiology of cardiovascular risk factors in maintenance dialysis patients. Kidney Int. 2003, 63, 793-808.

8. Kalantar-Zadeh, K.; Abbott, K.C.; Salahudeen, A.K.; Kilpatrick, R.D.; Horwich, T.B. Survival advantages of obesity in dialysis patients. Am. J. Clin. Nutr. 2005, 81, 543-554.

9. Kovesdy, C.P.; Kalantar-Zadeh, K. Why is protein-energy wasting associated with mortality in chronic kidney disease? Semin. Nephrol. 2009, 29, 3-14.

10. Stenvinkel, P. Inflammation in end-stage renal failure: could it be treated? Nephrol. Dial. Transpl. 2002, 17, S33-S38.

11. Chmielewski, M.; Carrero, J.J.; Qureshi, A.R.; Axelsson, J.; Heimburger, O.; Berglund, L.; Barany, P.; Rutkowski, B.; Lindholm, B.; Stenvinkel, P. Temporal discrepancies in the association between the apoB/apoA-I ratio and mortality in incident dialysis patients. J. Int. Med. 2009, 265, 708-716.

12. Chmielewski, M.; Verduijn, M.; Drechsler, C.; Lindholm, B.; Stenvinkel, P.; Rutkowski, B.; Boeschoten, E.W.; Krediet, R.; Dekker, F.W. Low Cholesterol in dialysis patients-causal factor for mortality or an effect of confounding? Nephrol. Dial. Transpl. 2011, doi:10.1093/ndt/gfr008.

13. Liu, Y.; Coresh, J.; Eustace, J.A.; Longenecker, J.C.; Jaar, B.; Fink, N.E.; Tracy, R.P.; Powe, N.R.; Klag, M.J. Association between cholesterol level and mortality in dialysis patients: Role of inflammation and malnutrition. JAMA 2004, 291, 451-459.

14. Contrerars, G.; Hu, B.; Astor, B.C.; Greene, T.; Erlinger, T.; Kusek, J.W.; Lipkowitz, M.; Lewis, J.A.; Randall, O.S.; Hebert, L.; et al. Malnutrition-Inflammation modifies the relationship of cholesterol with cardiovascular disease. J. Am. Soc. Nephrol. 2010, 21, 2131-2142. 
15. Topinkovà, E. Aging, disability and frailty. Ann. Nutr. Metab. 2008, 52, S6-S11.

16. Kalantar-Zadeh, K.; Block, G.; Horwich, T.; Fonarow, G.C. Reverse epidemiology of conventional cardiovascular risk factors in patients with chronic heart failure. J. Am. Coll. Cardiol. 2004, 21, 1439-1444.

17. Kalantar-Zadeh, K.; Kilpatrick, R.D.; Kuwae, N. Revisiting mortality predictability of serum albumin in the dialysis population: time dependency, longitudinal changes and population-attributable fraction. Nephrol. Dial. Transpl. 2005, 20, 1880-1888.

18. Kaysen, G.A.; Eiserich, J.P. The role of oxidative stress-altered lipoprotein structure and function and microinflammation on cardiovascular risk in patients with minor renal dysfunction. J. Am. Soc. Nephrol. 2004, 15, 538-548.

19. Lowrie, E.G.; Lew, N.L. Death risk in hemodialysis patients: the predictive value of commonly measured variables and an evaluation of death rate differences between facilities. Am. J. Kidney Dis. 1990, 15, 458-482

20. Reaich, D.; Price, S.R.; England, B.K.; Mitch, W.E. Mechanisms causing muscle loss in chronic renal failure. Am. J. Kidney Dis. 1995, 26, 242-247.

21. Khaw, K.T.; Dowsett, M.; Folkerd, E.; Bingham, S.; Wareham, N.; Luben, R.; Welch, A.; Day, N. Endogenous testosterone and mortality due to all causes, cardiovascular disease, and cancer in men: European prospective investigation into cancer in Norfolk (EPIC-Norfolk) Prospective Population Study. Circulation 2007, 116, 2694-2701.

22. Kaisar, O.M.; Johnson, D.W.; Prins, J.B.; Isbel, N. The role of novel biomarkers of cardiovascular disease in chronic kidney disease: focus on adiponectin and leptin. Curr. Cardiol. Rev. 2008, 4, 287-292.

23. Axelsson, J.; Witasp, A.; Carrero, J.J.; Qureshi, A.R.; Suliman, M.E.; Heimbürger, O.; Bárány, P.; Lindholm, B.; Alvestrand, A.; Schalling, M. Circulating levels of visfatin/pre-B-cell colonyenhancing factor 1 in rekation to genotype, GFR, body composition, and survival in patients with CKD. Am. J. Kidney Dis. 2007, 49, 237-244.

24. Zoccali, C.; Mallamaci, F.; Tripepi, G.; Cutrupi, S.; Pizzini, P. Low triiodothyronine and survival in end-stage renal disease. Kidney Int. 2006, 70, 523-528.

25. Carrero, J.J.; Qureshi, A.R.; Axelsson, J.; Yilmaz, M.I.; Rehnmark, S.; Witt, M.R.; Barany, P.; Heimburger, O.; Suliman, M.E.; et al. Clinical and biochemical implications of low thyroid hormone levels (total and free forms) in euthyroid patients with chronic kidney disease. J. Int. Med. 2007, 262, 690-701.

26. Ikizler, T.A.; Wingard, R.L.; Harvell, J.; Shyr, Y.; Hakim, R. Association of morbidity with markers of nutrition and inflammation in chronic hemodialysis patients: A prospective study. Kidney Int. 1999, 55, 1945-1951.

27. Foley, R.N.; Pafrey, P.S.; Harnett, J.D.; Kent, G.M.; Murray, D.C. Hypoalbuminemia, cardiac morbidity, and mortality in end-stage renal disease. J. Am. Soc. Nephrol. 1996, 7, 728-736.

28. Chertow, G.M.; Goldstein-Fuchs, D.J.; Lazarus, J.M.; Kaysen, G.A. Prealbumin, mortality, and cause-specific hospitalization in hemodialysis patients. Kidney Int. 2005, 68, 2794-2800.

29. Keys, A.; Brozek, J.; Henschel, A.; Mickelsen, O.; Taylor, H. The Biology of Human Starvation, Minneapolis; University of Minnesota Press: Minneapolis, MN, USA, 1950. 
30. Kopple, J.D.; Levey, A.S.; Greene, T.; Chumlea, W.C.; Gassman, J.J.; Hollinger, D.L.; Maroni, B.J.; Merrill, D.; Scherch, L.K.; Shulman, G.; et al. Effect of dietary protein restriction on nutritional status in the modification of diet in renal diseases study. Kidney Int. 1997, 52, 778-791.

31. Aparicio, M.; Chauveau, P.; De Precigout, V.; Bouchet, J.L.; Lasseur, C.; Combe, C. Nutrition and outcome on renal replacement therapy of patients with chronic renal failure treated by a supplemented very low protein diet. J. Am. Soc. Nephrol. 2000, 11, 708-716.

32. Gil, H.W.; Yang, J.O.; Lee, E.Y.; Lee, E.M.; Choi, J.S.; Hong, S.Y. The effect of dialysis membrane flux on amino acid loss in haemodialysis patients. J. Korean Med. Sci. 2007, 22, 598-603.

33. Kario, K.; Matsuo, T.; Kobyasahi, H. Heparin cofactor II deficiency in elderly: Comparison with antithrombin II. Thromb. Res. 1992, 66, 489-498.

34. Joles, J.A.; Willekes-Koolschij, N.; Koomas, H.A. Hypoalbuminemia causes high blood pressure by increasing red cell lysophosphatidylcholine. Kidney Int. 1997, 52, 761-770.

35. Emerson, T.E. Unique features of albumin: A brief review. Crit. Care Med. 1989, 17, 690-694.

36. Bergstrom, J. Nutrition and mortality in hemodialysis. J. Am. Soc. Nephrol. 1995, 6, 1329-1341.

37. Nguyen-Khoa, T.; Massay, Z.A.; De Bandt, J.P.; Kebede, M.; Salama, L.; Lambrey, G.; Witko-Sarsat, V; Drüeke, T.B.; Lacour, B; Thévenin, M. Oxidative stress and haemodialysis: Role of inflammation and duration of dialysis treatment. Nephrol. Dial. Transpl. 2001, 16, 335-340.

38. Zoccali, C.; Mallamaci, F.; Asahia, K.; Benedetto, F.A.; Tripepi, G.; Tripepi, R.; Nicocia, G.; Buemi, M.; Miyata, T. Pentosidine, carotid atherosclerosis and alterations in left ventricular geometry in hemodialysis patients. J. Nephrol. 2001, 14, 293-298.

39. Koyama, H.; Nishizawa, Y. AGEs/RAGE in CKD: Irreversible metabolic memory road toward CVD? Eur. J. Clin. Invest. 2010, 40, 623-635.

40. Nakashima, A.; Carrero, J.J.; Qureshi, A.R.; Miyamoto, T.; Anderstam, B.; Barany, P.; Heimburger, O.; Stenvinkel, P.; Lindholm, B. Effect of circulating soluble receptor for Advanced glycation End products (sRAGE) and the proinflammatory RADE Ligand (EN-RAGE, S100A12) on mortality in hemodialysis patients. Clin. J. Am. Soc. Nephrol. 2010, 5, 2213-2219.

41. Zhou, L.L.; Hou, F.F.; Wang, G.B.; Yang, F.; Xie, D.; Wang, Y.P.; Tian, J.W. Accumulation of advanced oxidation protein products induces podocyte apoptosis and deletion through NADPH-dependent mechanisms. Kidney Int. 2009, 76, 1125-1127.

42. Witko-Sarsat, V.; Gausson, V.; Nguyen, A.T.; Touam, M.; Drüeke, T.; Santangelo, F.; Descamps-Latscha, B. AOPP-induced activation of human neutrophil and monocyte oxidative metabolism: A potential target for $\mathrm{N}$-acetylcysteine treatment in dialysis patients. Kidney Int. 2003, 64, 82-91.

43. Descamps-Latscha, B.; Witko-Sarsat, V.; Nguyen-Khoa, T.; Nguyen, A.T.; Gausson, V.; Mothu, N.; London, G.M.; Jungers, P. Advanced oxidation protein products as risk factors for cardiovascular events in nondiabetic predialysis patients. Am. J. Kidney Dis. 2005, 45, 39-47.

44. Valli, A.; Mohamed, E.S.; Meert, S.; Vanholder, R.; Lindholm, B.; Stenvinkel, P.; Watanabe, M.; Barany, P.; Alvestrand, A.; Anderstam, B. Overestimation of advanced oxidation protein products in uremic plasma due to presence of triglycerides and other endogenous factors. Clin. Chim. Acta 2007, 379, 87-94. 
45. Panichi, V.; Migliori, M.; De Pietro, S.; Taccola, D.; Bianchi, A.M.; Giovannini, L.; Norpoth, M.; Metelli, M.R.; Cristofani, R.; Bertelli, A.A.; et al. C-reactive protein and interleukin-6 levels are related to renal function in predialytic chronic renal failure. Nephron 2002, 91, 594-600.

46. Stenvinkel, P.; Haimburger, O.; Paultre, F.; Diczfalusy, U.; Wang, T.; Berglund, L.; Jogestrand, T. Strong association between malnutrition, inflammation, and atherosclerosis in chronic renal failure. Kidney Int. 1999, 55, 1899-1911.

47. Yeun, J.Y.; Levine, R.A.; Mantadilok, V.; Kaysen, G.A. C-reactive protein predicts all-cause and cardiovascular mortality in haemodialysis patients. Am. J. Kidney Dis. 2000, 35, 469-476.

48. Eustace, J.A.; Astor, B.; Muntner, P.M.; Ikizler, T.A.; Coresh, J. Prevalence of acidosis and inflammation and their association with low serum albumin in chronic kidney disease. Kidney Int. 2004, 65, 1031-1040.

49. Schiffl, H.; Lang, S.M.; Stratakis, D.; Fischer, R. Effects of ultrapure dialysis fluid on nutritional status and inflammatory parameters. Nephrol. Dial. Transpl. 2001, 16, 1863-1869.

50. Cuneo, R.C.; Salomon, F.; Wiles, C.M.; Hesp, R.; Sönksen, P.H. Growth hormone treatment in growth hormone-deficient adults. I. Effects on muscle and strength. J. Appl. Physiol. 1991, 70, 688-694.

51. Bistrian, B.R.; Schwartz, J.; Istifan, N.W. Cytokines, muscle proteolysis and the catabolic response to infection and inflammation. Proc. Soc. Exp. Boil. Med. 1992, 200, 220-223.

52. Zwaka, P.T.; Hombach, V.; Torzewski, J. C-reactive protein-mediated low-density lipoprotein uptake by macrophages. Circulation 2001, 103, 1194-1197.

53. Boeheme, M.; Kaehene, F.; Kuehne, A.; Bernhardt, W.; Shroder, M.; Pommer, W.; Fiscer, C.; Becker, H.; Muller, C.; Schindler, R. Pentraxin 3 is elevated in haemodialysis patients and is associated with cardiovascular disease. Nephrol. Dial. Transpl. 2007, 22, 2224-2229.

54. Tong, M.; Carrero, J.J.; Qureshi, A.R.; Anderstam, B.; Heimburger, O.; Barany, P.; Axelsson, J.; Alvestrand, A.; Stenvinkel, P.; Lindholm, B.; et al. Plasma Pentraxin 3 in chronic kidney disease patients: Associations with renal function, protein-energy wasting, cardiovascular disease and mortality. Clin. J. Am. Soc. Nephrol. 2007, 2, 889-897.

55. Yilmaz, M.I.; Sonmez, A.; Ortiz, A.; Saglam, M.; kilic, S.; Eyileten, T.; Caglar, K.; Oguz, Y.; Vural, A.; Cakar, M.; et al. Soluble TWEAK and PTX3 in nondialysis CKD patients: impact on endothelial Dysfunction and cardiovascular outcomes. Clin. J. Am. Soc. Nephrol. 2011, 6, 785-792.

56. Alberti, L.; Gilardini, L.; Zulian, A.; Micheletto, G.; Peri, G.; Doni, A.; Mantovani, A.; Invitti, C. Expression of long pentraxin PTX3 in human adipose tissue and its relation with cardiovascular risk factors. Atherosclerosis 2009, 202, 455-460.

57. Raj, D.S.; Carrero, J.J.; Shah, V.O.; Qureshi, A.R.; Bárány, P.; Heimbürger, O.; Lindholm, B.; Ferguson, J.; Moseley, P.L.; Stenvinkel, P. Soluble CD14 levels, interleukin 6, and mortality among prevalent hemodialysis patiient. Am. J. Kidney Dis. 2009, 54, 1072-1080.

58. Shoji, T.; Shinohara, K.; Hatsuda, S.; Kimoto, E.; Fukumoto, S.; Emoto, M.; Tahara, H.; Koyama, H.; Ishimura, E.; Miki, T.; et al. Altered relationship between body fat and plasma adiponectin in end-stage renal disease. Metabolism 2005, 54, 330-334.

59. Honda, H.; Qureshi, A.R.; Axelsson, J.; Heimburger, O.; Suliman, M.E.; Barany, P.; Stenvinkel, P.; Lindholm, B. Obese sarcopenia in patients with end-stage renal disease is associated with inflammation and increased mortality. Am. J. Clin. Nutr. 2007, 86, 633-638. 
60. Kakiya, R.; Shoji, T.; Tsujimoto, Y.; Tatsumi, N.; Hatsuda, S.; Shinohara, K.; Kimoto, E.; Tahara, H.; Koyama, H.; Emoto, M.; et al. Body fat mass and lean mass as predictors of survival in hemodialysis patients. Kidney Int. 2006, 70, 549-556.

61. Kalantar-Zadeh, K.; Kuwae, N.; Wu, D.Y.; Shantouf, R.S.; Fouque, D.; Anker, S.D.; Block, G.; Kopple, J.D. Associations of body fat and its changes over time with quality of life and prospective mortality in hemodialysis patients. Am. J. Clin. Nutr. 2006, 83, 202-210.

62. Leinig, C.; Pecoits-Filho, R.; Nascimento, M.M.; Goncalves, S.; Riella, M.C.; Martins, C. Association between body mass index and body fat in chronic kidney disease stages 3 to 5 , hemodialysis, and peritoneal dialysis patients. J. Ren. Nutr. 2008, 18, 424-429.

63. Carrero, J.J.; Cordeiro, A.C.; Lindholm, B.; Stenvinkel, P. the emerging pleiotrophic role of adipokines in the uremic phenotype. Curr. Opin. Nephrol. Hypertens. 2010, 19, 37-42.

64. Zoccali, C.; Postorino, M.; Marino, C.; Pizzini, P.; Cutrupi, S.; Tripepi, G. CREDIT working group abdominal obesity and all-cause mortality in end-stage renal disease. J. Am. Coll. Cardiol. 2009, 53, 1265-1272.

65. Knudson, J.D.; Payne, G.A.; Borbouse, L.; Tune, J.D. Leptin and mechanisms of endothelial dysfunction and cardiovascular disease. Curr. Hypertens. Rep. 2008, 10, 434-439.

66. Liu, S.W.; Qiao, S.B.; Yuan, J.S.; Liu, D.Q. Association of plasma visfatin levels with inflammation, atherosclerosis and acute coronary syndrome(ACS) in humans. Clin. Endocrinol. 2009, 71, 202-207.

67. Schneiderman, J.; Simon, A.J.; Schroeter, M.R.; Flugelman, M.Y.; Konstantinides, S.; Schaefer, K. Leptin receptor is elevated in carotid plaques from neurologically symptomatic patients and positively correlated with augmented machrophage density. J. Vasc. Surg. 2008, 48, 1146-1155.

68. Dahl, T.B.; Yndestand, A.; Skjelland, M.; Oie, E.; Dahl, A.; Michelsen, A.; Damas, J.K.; Tunheim, S.H.; Ueland, T.; Smith, C.; et al. Increased expression of visfatin in macrophages of human unstable carotid and coronary atherosclerosis. Possible role in inflammation and plaque destabilization. Circulation 2007, 115, 972-980.

69. Ramkumar, N.; Pappas, L.M.; Beddhu, S. Effect of body size and body composition on survival in peritoneal dialysis patients. Perit. Dial. Int. 2005, 25, 461-469.

70. Huang, C.X.; Tighiouart, H.; Beddhu, S.; Cheung, A.K.; Dwyer, J.T.; Eknoyan, G.; Beck, G.J.; Levey, A.S.; Sarnak, M.J. Both low muscle mass and low fat are associated with higher all-cause mortality in hemodialysis patients. Kidney Int. 2010, 77, 624-629.

71. Noori, N.; Kovesdy, C.P.; Dukkipati, R.; Kim, Y.; Duong, U.; Bross, R.; Oreopoulos, A.; Luna, A.; Benner, D.; Kopple, J.D.; et al. Survival predictability of lean and fat mass in men and women undergoing maintenance hemodialysis. Am. J. Clin. Nut. 2010, 92, 1060-1070.

72. Tessari, P.; Deferrari, G.; Robaudo, C.; Vettore, M.; Pastorin, N.; De Biasi, L.; Garibotto, G.; Phenylalanine hydroxylation across the kidney in humans. Kidney Int. 1999, 56, 2168-2172.

73. Kopple, J.D. Phenylalanine and tyrosine metabolism in chronic kidney failure. J. Nutr. 2007, 137, 1586S-1590S.

74. Garibotto, G.; Sofia, A.; Saffioti, S.; Russo, R.; Deferrari, G.; Rossi, D.; Verzola, D.; Gandolfo, M.T.; Sala, M.R. Interorgan exchange of aminothiols in humans. Am. J. Physiol. Endocrinol. Metab. 2003, 284, E757-E763. 
75. Garibotto, G.; Valli, A.; Anderstam, B.; Eriksson, M.; Suliman, M.; Balbi, M.; Rollando, D.; Vigo, E.; Lindholm, B. The kidney is a major site of S-adenosylhomocysteine disposal in humans. Kidney Int. 2009, 76, 293-296.

76. Garibotto, G.; Sofia, A.; Saffioti, S.; Bonanni, A.; Mannucci, I.; Verzola, D. Amino acid and protein metabolism in the human kidney and in patients with chronic kidney disease. Clin. Nutr. 2010, 29, 424-433.

77. van de Poll, M.C.; Soesters, P.B.; Deutz, N.E.; Fearon, K.C.; Dejong, C.H.; Renal metabolism of amino acids: Its role in inter-organ amino acid exchange. Am. J. Clin. Nutr. 2004, 79, 185-197.

78. Lee, M.E.; Wang, H. Homocysteine and hypomethylation: a novel link to vascular disease. Trends Cardiovasc. Med. 1999, 9, 49-54.

79. Cantoni, G.L. Experimental and clinical roles of S-Adenosylmethionine. In Biological Methylation and Drug Design; Borchardt, R.T., Creveling, C.R., Ueland, P.M., Eds.; Humana Press: Clifton, NJ, USA, 1986; pp. 227-238.

80. Liu, C.; Wang, Q.; Guo, H.; Xia, M.; Yuan, Q.; Hu, Y. Plasma S-adenosylhomocysteine is a better biomarker of atherosclerosis than homocysteine in apolipoprotein E-deficient mice fed high dietary methionine. J. Nutr. 2008, 138, 311-315.

81. Valli, A.; Carrero, J.J.; Qureshi, A.R.; Garibotto, G.; Barany, P.; Axelsson, J.; Lindholm, B.; Stenvinkel, P.; Anderstam, B.; Suliman, M.E. Elevated serum levels of S-adenosylhomocysteine, but not homocysteine, are associated with cardiovascular disease in stage 5 chronic kidney disease patients. Clin. Chim. Acta 2008, 395, 106-110.

82. Ingrosso, D.; Cimmino, A.; Perna, A.F.; Masella, L.; De Santo, N.G.; De Bonis, M.L.; Vacca, M.; D’Esposito, M.; D’Urso, M.; Galletti, P.; et al. Folate treatment and unbalanced methylation and changes of allelic expression induced by hyperhomocysteinaemia in patients with uraemia. Lancet 2003, 17, 1693-1694.

83. Baylis, C. Arginine, arginine analogous and nitric oxid production in chronic kidney disease. Nat. Clin. Pract. Nephrol. 2006, 2, 209-220.

84. Matsuoka, H. Endothelial dysfunction associated with oxidative stress in human. Diabetes Res. Clin. Pract. 2001, 54, S65-S72.

85. Kielstein, J.T.; Zoccali, C. Asymmetric dimethylarginine: A novel marker of risk and potential target for therapy in chronic kidney disease. Curr. Opin. Nephrol. Hyperten. 2008, 17, 609-615.

86. Vallance, P.; Leone, A.; Calver, A.; Collier, J.; Moncada, S. Accumulation of an endogenous inhibitor on nitric oxide synthesis in chronic renal failure. Lancet 1992, 339, 572-575.

87. Mihout, F.; Shweke, N.; Bigé, N.; Jouanneau, C.; Dussaule, J.C.; Ronco, P.; Chatziantoniou, C.; Boffa, J.J. Asymmetric dimethylarginine (ADMA) induces chronic kidney disease through a mechanism involving collagen and TGF- $\beta 1$ synthesis. J. Pathol. 2011, 223, 37-45.

88. Cross, J.M.; Donald, A.; Vallance, P.; Deanfield, J.E.; Woolfson, R.G.; MacAllister, R.J. Hemodialysis improves endothelial function in humans. Nephrol. Dial. Transpl. 2001 16, 1823-1829.

89. Kaskel, F. Chronic renal disease: A growing problem. Kidney Int. 2003, 64, 1141-1151.

90. Qing, D.P.; Ding, H.U.; Vagdama, J. Elevated myocardial cytosolic calcium impairs insulin-like growth factor-1 stimlated protein synthesis in chronic renal failure. J. Am. Soc. Nephrol. 1999, 10, 84-91. 
91. Blum, W.F.; Ranke, M.B.; Kietzmann, K.; Tönshoff, B.; Mehls, O. growth hormone resistance and inhibition of somatomedin activity by excess of insulin-like growth factor binding protein in uremia. Pediatr. Nephrol. 1991, 5, 539-544.

92. Sun, D.F.; Zheng, Z.; Tummala, P.; Oh, J.; Schaefer, F.; Rabkin, R. Chronic uremia attenuates growth hormone-induced signal transduction in skeletal muscle. J. Am. Soc. Nephrol. 2004, 15, 2630-2646.

93 Chen, Y.; Biada, J.; Sood, S.; Rabkin, R. Uremia attenuates growth hormone-stimulated insulin-like growth factor-1 expression, a process worsened by inflammation. Kidney Int. 2010, 78, 89-95.

94. Cooney, R.N.; Shumate, M. The inhibitory effects of interleukin-1 on growth hormone action during catabolic illness. Vitam. Horm. 2006, 74, 317-340.

95. Brungger, M.; Hulter, H.N.; Krapf, R. Effect of chronic metabolic acidosis on the growth hormone/IGF-1 endocrine axis: new cause of growth hormone insensitivity in humans. Kidney Int. 1997, 51, 216-221.

96 Garibotto, G.; Russo, R.; Sofia, A.; Ferone, D.; Fiorini, F.; Cappelli, V.; Tarroni, A.; Gandolfo, M.T.; Vigo, E.; Valli, A.; et al. Effects of uremia and inflammation on growth hormone resistance in patients with chronic kidney disease. Kidney Int. 2008, 74, 937-945.

97. Bhasin, S.; Taylor, W.E.; Singh, R.; Artaza, J.; Sinha-Hikim, I.; Jasuja, R.; Choi, H.; Gonzalez-Cadavid, N.F. The mechanisms of androgen effects on body composition: mesenchymal pluripotent cell as the target of androgen action. J. Gerontol. Med. Sci. 2003, 58, 1103-1110.

98. Wolfe, R.; Ferrando, A.; Sheffield-Moore, M.; Urban, R. Testosterone and muscle protein metabolism. Mayo Clin. Proc. 2000, 75, S55-S59.

99. Harman, S.M.; Metter, E.J.; Tobin, J.D.; Pearson, J.; Blackman, M.R. Baltimore longitudinal study of aging. Longitudinal effects of aging on serum total and free testosterone levels in healthy men. J. Clin. Endocrinol. Metab. 2001, 86, 724-731.

100. Morley, J.E.; Melmed, S. Gonadal dysfunction in systemic disorders. Metabolism 1979, 28, 1051-1073.

101. Roubenoff, R.; Parise, H.; Payette, H.A.; Abad, L.W.; D'Agostino, R.; Jacques, P.F.; Wilson, P.W.; Dinarello, C.A.; Harris, T.B. Cytokines, insulin-like growth factor 1, sarcopenia, and mortality in very old communitydwelling men and women: the Framingham Heart Study. Am. J. Med. 2003, 115, 429-435.

102. Haring, R.; Nauck, M.; Volzke, H.; Endlich, K., Lendeckel, U.; Friedrich, N.; Dorr, M.; Rettig, R.; Kroemer, H.K.; Wallaschofski, H. Low serum testosterore is associated with increased mortality in men with stage 3 or greater nephropathy. Am. J. Nephrol. 2011, 33, 209-217.

103. Khaw, K.T.; Dowsett, M.; Folkerd, E.; Bingham, S.; Wareham, N.; Luben, R.; Welch, A.; Day, $\mathrm{N}$. Endogenous testosterone and mortality due to all causes, cardiovascular disease, and cancer in men: European prospective investigation into cancer in Norfolk (EPIC-Norfolk) prospective population study. Circulation 2007, 116, 2694-2701.

104. Carrero, J.J.; Qureshi, A.R.; Parini, P.; Arver, S.; Lindholm, B.; Bárány, P.; Heimbürger, O.; Stenvinkel, P. Low serum testosterone increases mortality risk among male dialysis patients. J. Am. Soc. Nephrol. 2009, 20, 613-620. 
105. Gungor, O.; Kircelli, F.; Carrero, J.J.; Asci, G.; Toz, H.; Tatar, E.; Hur, E.; Sever, M.S.; Arinsoy, T.; Ok, E. Endogenous testosterone and mortality in male hemodialysis patients: Is this the resul of aging? Clin. J. Am. Soc. Nephrol. 2010, 5, 2018-2023.

106. Alvestrand, A.; DeFronzo, R.A.; Smith, D.; Wahren, J. Influence of Hyperinsulinemia on intracellular amino acids levels and amino acid exchange across splanchnic and leg tissues in uremia. Clin. Sci. 1988, 74, 155-162.

107. Bailey, J.L.; Zheng, B.; Hu, Z.; Price, S.R.; Mitch, W.E. Chronic kidney disease causes defects in signalling through the insulin receptor substrate/phosphatidylinositol 3-kinase/Akt pathway: Implications for muscle atrophy. J. Am. Soc. Nephrol. 2006, 17, 1388-1394.

108. Pupim, L.B.; Flakoll, P.J.; Majchrzak, K.M.; Aftab Guy, D.L.; Stenvinkel, P.; Ikizler, T.A. Increased muscle protein breakdown in chronic hemodialysis patients with type 2 diabetes mellitus. Kidney Int. 2005, 68, 1857-1865.

109. Rajan, V.; Mitch, W.E. Ubiquitin, proteasomes and proteolytic mechanisms activated by kidney disease. Biochim. Biophys. Acta 2008, 1782, 795-799.

110. Reaich, D.; Channo, S.M.; Scrimgeour, C.M.; Daley, S.E.; Wilkinson, R.; Goodship, T.H. Correction of acidosis in humans with CRF decreases protein degradation and amino acid oxidation. Am. J. Physiol. 1993, 265, E230-E235.

111. Burrowes, J.D.; Larive, B.; Chertow, G.M. Self-reported appetite, hospitalization and death in haemodialysis patients: findings from the haemodialysis (HEMO) study. Nephrol. Dial. Transpl. 2005, 20, 2765-2774.

112. Cheung, W.; Yu, P.X.; Little, B.M. Role of leptin and melanocortin signaling in uremiaassociated cachexia. J. Clin. Invest. 2005, 115, 1659-1665.

113. Kalantar Zadeh, K.; Block, G.; Mc Allister, C.J.; Humphreys, M.H.; Kopple, J.D. Appetite and inflammation, nutrition, anemia, and clinical outcome in hemodialysis patients. Am. J. Clin. Nutr. 2004, 80, 299-307.

114. Carrero, J.J.; Qureshi, A.R.; Axelsson, J.; Avesani, C.M.; Suliman, M.E.; Kato, S.; Bárány, P.; Snaedal-Jonsdottir, S.; Alvestrand, A.; Heimbürger, O.; et al. Comparison of nutritional and inflammatory markers in dialysis patients with reduced appetite. Am. J. Clin. Nutr. 2007, 85, 695-701.

115. Gayle, D.A.; Desai, M.; Casillas, E.; Belooseski, R.; Ross, M.G. Gender specific orexigenic and anorexigenic mechanisms in rats. Life Sci. 2006, 79, 1531-1536.

116. Latos, D.L. Chronic dialysis in patients over age 65. J. Am. Soc. Nephrol. 1996, 7, 637-646.

117. Lindeman, R.D. Overview: Renal physiology and pathophysiology of aging. Am. J. Kidney Dis. 1990, 16, 275-282.

118. Timiras, P.S. Aging of the Skeleton, Joints and Muscles. In Physiological Basis of Aging and Geriatrics, 2nd ed.; Timiras, P.D., Ed.; CRC Press: Boca Raton, FL, USA, 1994; pp. 259-272.

119. Rothstein, M. Altered proteins, errors and aging. In Protein Metabolism in Aging; Segal, H.L., Rothstein, M., Bergamini, P., Eds.; Wiley-Liss Inc.: New York, NY, USA, 1990; pp. 3-14.

120. Gersovitz, M.; Bier, D.; Matthews, D.; Udall, J.; Munro, H.N.; Young, V.R. Dynamic aspects of whole body glycine metabolism. Influence of protein intake in young adult and elderly males. Metabolism 1980, 29, 1087-1094. 
121. Robert, J.J.; Bier, D.; Schoeller, D.; Wolfe, R.; Matthews, D.E.; Munro, H.N.; Young, V.R. Effect of intravenous glucose on whole body leucine dynamics, studied with 1-13C-leucine, in healthy, young and elderly adults. J. Gerontol. 1984, 39, 673-681.

122. Nair, K.S. Age-related changes in muscle. Mayo. Clin. Proc. 2000, 75S, S14-S18.

123. Boirie, Y.; Gachon, P.; Cordat, N.; Ritz, P.; Beaufrère, B. Differential insulin sensitivities of glucose, amino acid, and albumin metabolism in elderly men and women. J. Clin. Endocrinol. Metab. 2001, 86, 638-644.

124. Oreopoulos, A.; Kalantar-Zadeh, K.; Sharma, A.M.; Fonarow, G.C. The obesity paradox in the elderly: Potential mechanisms and clinical implications. Clin. Geriatr. Med. 2009, 25, 643-659.

125. Miller, S.L.; Wolfe, R.R. The danger of weight loss in the elderly. J. Nutr. Health Aging. 2008, 12, 487-489.

126. Vanholder, R.; Ringoir, S. Infectious morbidity and defects of phagocytic function in end-stage renal disease: A review. J. Am. Soc. Nephrol. 1993, 3, 1541-1554.

127. Dalrymple, L.S.; Go, A.S. Epidemiology of acute infections among patients with chronic kidney disease. Clin. J. Am. Soc. Nephrol. 2008, 3, 1487-1493.

128. Allon, M.; Depner, T.A.; Radeva, M.; Bailey, J.; Beddhu, S.; Butterly, D.; Coyne, D.W.; Gassman, J.J.; Kaufman, A.M.; Kaysen, G.A.; et al. Impact of dialysis dose and membrane on infection-related hospitalization and death: Results of the HEMO Study. J. Am. Soc. Nephrol. 2003, 14, 1863-1870.

129. Chinen, J.; Shearer, W.T. Secondary immunodeficiencies, including HIV infection. J. Allergy Clin. Immunol. 2008, 121, S388-392.

130. Hulsewe, K.W.; van Acker, B.A.; Von Meyenfeldt, M.F.; Soeters, P.B. Nutritional depletion and dietary manipulation: Effects on the immune response. World J. Surg. 1999, 23, 536-544.

131. Souba, W.W. Nutritional support. N. Engl. J. Med. 1997, 336, 41-48.

132. Alexander, J.W. Immunoenhancement via enteral nutrition. Arch. Surg. 1993, 128, 1242-1245.

133. Kimmel, P.L.; Phillips, T.M.; Lew, S.Q.; Langman, C.B. Zinc modulates mononuclear cellular calcitriol metabolism in peritoneal dialysis patients. Kidney Int. 1996, 49, 1407-1412.

134. Erten, Y.; Kayatas, M.; Sezer, S.; Kayataş, M.; Haberal, A.; Güz, G.; Erten, Y.; Hizel, N.; Boyacioğlu, S.; Gülmüş, S.; et al. Zinc deficiency: Prevalence and causes in hemodialysis patients and effect on cellular immune response. Transpl. Proc. 1998, 30, 850-851.

135. Casciato, D.A.; McAdam, L.P.; Kopple, J.D.; Bluestone, R.; Goldberg, L.S.; Clements, P.J.; Knutson, D.W. Immunologic abnormalities in hemodialysis patients: Improvement after pyridoxine therapy. Nephron 1984, 38, 9-16.

136. Dobbelstein, H.; Korner, W.F.; Mempel, W.; Grosse-Wilde, H.; Edel, H.H. Vitamin B6 deficiency in uremia and its implications for the depression of immune responses. Kidney Int. 1974, 5, 233-239.

137. Minnaganti, V.R.; Cunha, B.A. Infections associated with uremia and dialysis. Infect. Dis. Clin. North Am. 2001, 15, 385-406.

138. Cohen, G.; Haag-Weber, M.; Horl, W.H. Immune dysfunction in uremia. Kidney Int. Supp. 1997, 62, S79-S82. 
139. Pesanti, E.L. Immunologic defects and vaccination in patients with chronic renal failure. Infect. Dis. Clin. North Am. 2001, 15, 813-832.

140. Eleftheriadis, T.; Antoniadi, G.; Liakopoulos, V.; Kartsios, C.; Stefanidis, I. Disturbances of acquired immunity in hemodialysis patients. Semin. Dial. 2007, 20, 440-451.

141. Lim, W.H.; Kireta, S.; Leedham, E.; Russ, G.R.; Coates, P.T. Uremia impairs monocyte and monocyte-derived dendritic cell function in hemodialysis patients. Kidney Int. 2007, 72, 1138-1148.

142. Fantuzzi, G.; Faggioni, R. Leptin in the regulation of immunity, inflammation, and hematopoiesis. J. Leukoc. Biol. 2000, 68, 437-446.

143. Matarese, G.; La Cava, A.; Sanna, V.; Lord, G.M.; Lechler, R.I.; Fontana, S.; Zappacosta, S. Balancing susceptibility to infection and autoimmunity: A role for leptin? Trends Immunol. 2002, 23, 182-187.

144. Madej, T.; Boguski, M.S.; Bryant, S.H. Threading analysis suggests that the obese gene product may be a helical cytokine. FEBS Lett. 1995, 373, 13-18.

145. Baumann, H.; Morella, K.K.; White, D.W.; Dembski, M.; Bailon, P.S.; Kim, H.; Lai, C.F.; Tartaglia, L.A. The full-length leptin receptor has signaling capabilities of interleukin 6-type cytokine receptors. Proc. Natl. Acad. Sci. USA 1996, 93, 8374-8378.

146. Lord, G.M.; Matarese, G.; Howard, J.K.; Baker, R.J.; Bloom, S.R.; Lechler, R.I. Leptin modulates the T-cell immune response and reverses starvation-induced immunosuppression. Nature 1998, 394, 897-901.

147. Loffreda, S.; Yang, S.Q.; Lin, H.Z.; Karp, C.L.; Brengman, M.L.; Wang, D.J.; Klein, A.S.; Bulkley, G.B.; Bao, C.; Noble, P.W.; Lane, M.D.; Diehl, A.M. Leptin regulates proinflammatory immune responses. FASEB J. 1998, 12, 57-65.

148. Gabay, C.; Dreyer, M.G.; Pellegrinelli, N.; Chicheportiche, R.; Meier, C.A. Leptin directly induces the secretion of interleukin 1 receptor antagonist in human monocytes. Clin. Endocrinol. Metab. 2001, 86, 783-791.

149. Santos-Alvarez, J.; Goberna, R.; Sanchez-Margalet, V. Human leptin stimulates proliferation and activation of human circulating monocytes. Cell Immunol. 1999, 194, 6-11.

150. Sanchez-Margalet, V.; Martin-Romero, C.; Santos-Alvarez, J.; Goberna, R.; Najib, S.; Gonzalez-Yanes, C. Role of leptin as an immunomodulator of blood mononuclear cells: Mechanism of action. Clin. Exp. Immunol. 2003, 133, 11-19.

151. Matarese, G.; La Cava, A. The intricate interface between immune system and metabolism. Trends Immunol. 2004, 25, 193-200.

152. Rajala, M.W.; Scherer, P.E. The adipocyte. At the crossroads of energy homeostasis, inflammation, and atherosclerosis. Endocrinology 2003, 144, 3765-3773.

153. Diez, J.J.; Iglesias, P.; Fernandez-Reyes, M.J.; Aguilera, A.; Bajo, M.A.; Alvarez-Fidalgo, P.; Codoceo, R.; Selgas, R. Serum concentrations of leptin, adiponectin and resistin, and their relationship with cardiovascular disease in patients with end-stage renal disease. Clin. Endocrinol. 2005, 62, 242-249. 
154. McTernan, P.G.; Fisher, F.M.; Valsamakis, G.; Chetty, R.; Harte, A.; McTernan, C.L.; Clark, P.M.; Smith, S.A.; Barnett, A.H.; Kumar, S. Resistin and type 2 diabetes: regulation of resistin expression by insulin and rosiglitazone and the effects of recombinant resistin on lipid and glucose metabolism in human differentiated adipocytes. J. Clin. Endocrinol. Metab. 2003, 88, 6098-6106.

155. Cohen, G.; Ilic, D.; Raupachova, J.; Hörl W.H. Resistin inhibits essential functions of polymorphonuclear leukocytes. J. Immunol. 2008, 181, 3761-3768.

156. Lim, V.S.; Kopple, J.D. Protein metabolism in patients with chronic renal failure: Role of uremia and dialysis. Kidney Int. 2000, 58, 1-10.

157. Mitch, W.E. Malnutrition: A frequent misdiagnosis for hemodialysis patients. J. Clin. Invest. 2002, 110, 437-439.

158. Stevinkel, P.; Heimburger, O.; Lindholm, B. Wasting, but not malnutrition, predicts cardiovascular mortality in end-stage renal disease. Nephrol. Dial. Transpl. 2004, 19, 2181-2183.

159. Mitch, W.E.; Goldberg, A.L. Mechanisms of muscle wasting: The role of ubiquitin-proteasome system. N. Engl. J. Med. 1996, 335, 1897-1905.

160. Lecker, S.H.; Goldberg, A.L.; Mitch, W.E. Protein degradation by the ubiquitin-proteasome pathway in normal and disease states. J. Am. Soc. Nephrol. 2006, 17, 1807-1819.

161. Dupont-Versteegden, E.E. Apoptosis in skeletal muscle and its relevance to atrophy. World J. Gastroenterol. 2006, 12, 7463-7466.

162. Gundersen, K.; Bruusgaard, J.C. Nuclear domains during muscle atrophy: Nuclei lost or paradigm lost? J. Physiol. 2008, 586, 2675-2681.

163. Frost, R.A.; Lang, C.H. Protein kinase B/Akt: A nexus of growth factor and cytokine signaling in determining muscle mass. J. Appl. Physiol. 2007, 103, 378-387.

164. Yamaguchi, H.; Wang, H.G. The protein kinase PKB/Akt regulates cell servival and apoptosis by inhibiting Bax conformational change. Oncogene 2001, 20, 7779-7786.

165. Lee, S.W.; Dai, G.; Hu, Z.; Wang, X.; Du, J.; Mitch, W.E. Regulation of muscle protein degradation: Coordinated control of apoptotic and ubiquitin-proteasome systems by phosphatidynositol 3 kinase. J. Am. Soc. Nephrol. 2004, 15, 1537-1545.

166. Zhang, L.; Wang, X.H.; Wang, H.; Du, J.; Mitch, W.E. Satellite cell dysfunction and impaired IGF-I signaling cause CKD-induced muscle atrophy. J. Am. Soc. Nephrol. 2010, 21, 419-427.

167. Zhang, L.; Ran, L.; Garcia, G.E.; Wang, X.H.; Han, S.; Du, J.; Mitch, W.E. Chemokine CXCL16 regulates neutrophil and macrophage infiltration into injured muscle promoting muscle regeneration. Am. J. Pathol. 2009, 175, 2518-2527.

168. Verzola, D.; Procopio, V.; Sofia, A.; Villaggio B.; Tarroni, A.; Bonanni, A.; Mannucci, I.; De Cian, F.; Gianetta, E.; Saffioti, S.; Garibotto, G. Apoptosis and myostatin mRNA are upregulated in skeletal muscle of patients with chronic kidney disease. Kidney Int. 2011, 79, 773-782.

169. Garibotto, G.; Russo, R.; Sofia, A.; Sala, M.R.; Robaudo, C.; Moscatelli, P.; Deferrari, G.; Tizianello, A. Skeletal muscle protein synthesis and degradation in patients with chronic renal failure. Kidney Int. 1994, 45, 1432-1439. 
170. Hara, Y.; May, R.C.; Kelly, R.A.; Mitch, W.E. Acidosis, not azotemia, stimulates branched-chain, amino acid catabolism in uremic rats. Kidney Int. 1987, 32, 808-814.

171. Reaich, D.; Channon, S.M.; Scrimgeour, C.M.; Daley, S.E. Wilkinson, R.; Goodship, T.H. Correction of acidosis in humans with CRF decreases protein degradation and amino acid oxidation. Am. J. Physiol. 1993, 265, E230-E235.

172. Young, G.A.; Swanepoel, C.R.; Croft, M.R.; Hobson, S.M.; Parsons, F.M. Anthropometry and plasma valine, amino acids, and proteins in the nutritional assessment of hemodialysis patients. Kidney Int. 1982, 21, 492-499.

173. Kornasion, R.; Riederer, I.; Butler-Browne, G.; Mouly, V.; Uni, Z.; Halevy, O. Beta-hydroxy-beta-methylbutyrate (HMB) stimulates myogenic cell proliferation, differentiation and survival via the MAPK/ERK and PI3K/Akt pathways. Biochim. Biophys. Acta 2009, 1793, 755-763.

(C) 2011 by the authors; licensee MDPI, Basel, Switzerland. This article is an open access article distributed under the terms and conditions of the Creative Commons Attribution license (http://creativecommons.org/licenses/by/3.0/). 